\title{
How Do the Time-Varying Risk Prices Behave in Japan? An Investigation with a Multivariate GARCH-CAPM Approach
}

\author{
Chikashi Tsuji \\ Graduate School of Systems and Information Engineering, University of Tsukuba, 1-1-1 Tennodai, Tsukuba, Ibaraki \\ 305-8573, Japan
}

\begin{abstract}
This paper examines the pricing of month-by-month time-varying risks on the Japanese stock market over the period from 1981 to 2004. Using the multivariate GARCH model, we tested the conditional version of the Sharpe-LintnerMossin CAPM. In contrast to previous studies, we derive and focus strictly on the monthly time-varying risk prices while employing the Fama and French approach by constructing 25 size-ranked and 25 BE/ME-ranked portfolio returns. The empirical results show that the price of risk in the conditional version of the Sharpe-Lintner-Mossin CAPM is generally positive and significant when the time-varying covariances from the multivariate GARCH model are used. This provides evidence contrary to the findings of many international studies in which the validity of the traditional CAPM is very often denied.
\end{abstract}

Keywords: Conditional CAPM, multivariate GARCH model, time-varying risk aversion, time-varying risk price.

\section{INTRODUCTION}

The time-varying characteristics of both covariance risks and the prices of risk are clearly crucial for asset pricing. However, in many related earlier studies, including Harvey [1], Campbell [2], Hansson and Hördahl [3], and Guo [4], time-varying risk prices were not analyzed specifically. Thus, the dynamics of the risk prices and the degree of pricing of the risks from a time-series viewpoint appears to be unclear in existing literature.

From this specific viewpoint and motivation, the primary objective of this analysis is to reveal the dynamics of the timevarying prices of risk in the traditional asset-pricing model. Our interest lies particularly in clarifying the monthly statistical significance of the time-varying risk prices. To avoid blurring this motivation for our research, we focus solely on the conditional version of the Sharpe [5]-Lintner [6]-Mossin capital asset pricing model (CAPM) in this paper.

To conduct our investigation to achieve the above goal, we construct 25 portfolios ranked by book equity relative to market equity (BE/ME) and 25 portfolios ranked by size, following Fama and French [7]. We then use a multivariate generalized autoregressive conditional heteroscedasticity (GARCH) model to derive the time-varying covariance risks. By exploiting the covariances and performing cross-sectional regressions month-by-month in Japan, we inspect the monthly position of the time-varying risk prices. From a methodological point of view, research into asset pricing using multivariate GARCH models seems limited. ${ }^{1}$

*Address correspondence to this author at the Graduate School of Systems and Information Engineering, University of Tsukuba, 1-1-1 Tennodai, Tsukuba, Ibaraki 305-8573, Japan; E-mail: mail_sec_low@minos.ocn.ne.jp

${ }^{1}$ Bollerslev, Engle, and Wooldridge [8] performed one of the first multivariate analyses in a test of the CAPM. Other studies that have analyzed asset-pricing models using the multivariate GARCH model include Engle and Kroner [9], Koutmos and Booth [10], Braun, Nelson, and Suiner [11], Kroner and $\mathrm{Ng}$ [12], and Leon, Nave, and Rubio [13]. In the above studies, risk prices were not their main focus.
Therefore, clarifying the monthly statistical significance of time-varying risk prices in Japan using the multivariate GARCH model is the main contribution of this paper.

The remainder of this paper is organized as follows. Section II presents the model and the methodology. Section III describes the data employed, Section IV supplies the empirical results, and Section V provides their interpretation. Finally, Section VI presents our conclusions.

\section{MODEL AND METHODOLOGY}

As mentioned, we focus on the conditional CAPM. The model for period $t$ is an equilibrium relation for the conditional expected return of an asset in excess of the risk-free rate when agents use the information available at the end of period $t-1$ :

$$
\begin{aligned}
& E\left[\left(r_{i, t}-r_{f, t}\right) \mid \Omega_{t-1}\right]=\frac{E\left[\left(r_{m, t}-r_{f, t}\right) \mid \Omega_{t-1}\right]}{\operatorname{Var}\left[r_{m, t} \mid \Omega_{t-1}\right]} \operatorname{Cov}\left[r_{i, t}, r_{m, t} \mid \Omega_{t-1}\right] \\
& =\beta_{i, t} E\left[\left(r_{m, t}-r_{f, t}\right) \mid \Omega_{t-1}\right] . \\
& \beta_{i, t} \equiv \frac{\operatorname{Cov}\left[r_{i, t}, r_{m, t} \mid \Omega_{t-1}\right]}{\operatorname{Var}\left[r_{m, t} \mid \Omega_{t-1}\right]}
\end{aligned}
$$

where $r_{i, t}$ and $r_{m, t}$ are the one-period returns on an asset $i$ and the market portfolio, respectively, $r_{f, t}$ is the one-period riskfree rate, and $\Omega_{t-1}$ is the information available to the markets at time $t-1$.

In the preceding studies, such as Hansson and Hördahl [3], among others, the price of risk is stable over time. However, in this paper, we do not assume that the price of risk is constant but rather assume that it is time varying:

$\delta_{t} \equiv \frac{E\left[\left(r_{m, t}-r_{i, t}\right) \mid \Omega_{t-1}\right]}{\operatorname{Var}\left[r_{m, t} \mid \Omega_{t-1}\right]}$.

Thus, we have the following conditional version of the CAPM for a single asset $i$ : 


$$
E\left[\left(r_{i, t}-r_{f, t}\right) \mid \Omega_{t-1}\right]=\delta_{t} \operatorname{Cov}\left[r_{i, t}, r_{m, t} \mid \Omega_{t-1}\right]
$$

In this formulation, the estimation of the time-varying covariances, $\operatorname{Cov}\left[r_{i, t}, r_{m, t} \mid \Omega_{t-1}\right]$, is necessary for inspecting the statistical significance of the time-varying price of risk, $\delta_{t}$. Thus, for the estimation of the time-varying covariances, we use the multivariate BEKK-GARCH model in this paper. ${ }^{2}$

The BEKK version of the multivariate GARCH model was introduced by Engle and Kroner [9]. This BEKK model ensures that the $\mathbf{H}$ matrix is always positive definite, and is specified by $\mathbf{H}_{t}=\mathbf{W}+\mathbf{B}^{\prime} \mathbf{H}_{t-1} \mathbf{B}+\mathbf{A}^{\prime} \Xi_{t-1} \Xi_{t-1}^{\prime} \mathbf{A}$. In the case of two assets, $\mathbf{W}, \mathbf{A}$, and $\mathbf{B}$ are $2 \times 2$ matrices of parameters, and $\mathbf{W}$ is assumed to be symmetric and positive definite. We estimate the parameters of the BEKK model by the maximum-likelihood method.

\section{DATA AND PORTFOLIO CONSTRUCTIONS}

Our data sample period is from October 1981 to July 2004. The individual data series are outlined below. The notations of the data are the risk-free percentage rate, $R_{f, t}$, the market portfolio percentage return, $R_{m, t}$, and the returns of 25 portfolios constructed using stocks listed on the First Section of the Tokyo Stock Exchange (TSE), $r_{i, t}$.

First, $R_{f}$ is the Gensaki rate from the Japan Securities Dealers Association from October 1981 to May 1984 and the one-month median rate on negotiable-time certificates of deposit (CD) from the Bank of Japan from June 1984 to July $2004^{3}$. The market return $R_{m}$ is the value-weighted return of all stocks in the TSE First Section, which is provided by the Japan Securities Research Institute (JSRI).

In regards to the 25 portfolio returns, we constructed 25 size-ranked portfolio returns and $25 \mathrm{BE} / \mathrm{ME}-$ ranked portfolio returns, following the manner of Fama and French [7]. Individual stock return data used for constructing these portfolios are all TSE First Section-listed stocks' returns from the JSRI. To construct the size-ranked portfolios, all TSE First Section stocks are first allocated to one of 25 groups based on their ME (stock price $\times$ shares outstanding) at the end of September of each year $t$ for the period from 1981 to 2003. Then, value-weighted monthly returns on the portfolios are calculated from the following October to the next September. When constructing the $\mathrm{BE} / \mathrm{ME}$ portfolios, the $\mathrm{BE} / \mathrm{ME}$ ratio that is used to form the portfolios in September of year $t$ is the book common equity for the fiscal year $t-1$, divided by the market equity at the end of March in calendar year $t .{ }^{4} \mathrm{We}$

\footnotetext{
${ }^{2}$ As an excellent survey by Bauwens, Laurent, and Rombouts [14] argued, the multivariate GARCH model is crucially important in the context of asset pricing as the model is useful for calculating the time-varying covariances or factor loadings.

${ }^{3}$ Before June 1984, one-month CD rates are not available. Thus, following Hamao [15], we specified the Gensaki rate as the risk-free rate before June 1984.

${ }^{4}$ We rebalanced the portfolios every September following the suggestion of Fama and French [7]: "We calculate returns beginning in July of year $t$ to be sure that book equity for year $t-1$ is known" (Fama and French [7, p. 9]). In Japan, the end of the fiscal year when most companies close is not at the end of December as in the United States, but at the end of March; that is, the end of the fiscal year in Japan is three months after that in the United States. Thus, we calculate returns, not from July but from October of year $t$ to Sep-
}

do not use negative $\mathrm{BE}$ firms when forming the $\mathrm{BE} / \mathrm{ME}$ portfolios. The value-weighted monthly returns on the BE/ME portfolios are then calculated from October to the following September, as were the size-ranked portfolios. Further, only firms with ordinary common equity are included in our analysis. This means that real estate investment trusts (REITs) and beneficial interest units are excluded. ${ }^{5}$

\section{EMPIRICAL RESULTS}

This section provides our empirical results and their interpretation. First, applying equation (4) cross-sectionally month by month, we obtain the monthly time-varying prices of risk from the conditional CAPM on the size-ranked and $\mathrm{BE} / \mathrm{ME}-$ ranked portfolios. Because each regression comprises a cross-section, heteroscedasticity-consistent covariance matrix of White [16] is used to calculate the $p$-values. Table 1 displays the monthly time-varying prices of risk from the conditional CAPM for the portfolios formed on the basis of size for the period from January 1982 to December 2003. From Table 1, we understand that, in general, the monthly time-varying prices of risk from the conditional CAPM are statistically significant, and that 135 of the 264 cases involve significant risk prices with theoretically consistent positive signs.

Table 2 also displays the monthly time-varying prices of risk from the conditional CAPM for the portfolios formed on the basis of BE/ME for the same sample period as in Table $\mathbf{1}$. The trends found are very similar to those of the size-ranked portfolios. In general, the monthly time-varying prices of risk from the conditional CAPM are also statistically significant for the BE/ME-ranked portfolios, and 123 of the 264 cases involve significant risk prices with positive signs.

Finally, to further evaluate the conditional CAPM for a longer time span, we present the results of the balanced panel data analysis in Table 3. This table displays the results for the whole sample period from October 1981 to July 2004 and for four sub-sample periods. Table 3 suggests that the risk prices from the conditional CAPM are statistically significant for all testing periods and for both size- and BE/MEranked portfolios, with the exception of the BE/ME portfolios over the period from January 1987 to December 1992. Hence, the conditional CAPM is supported by actual stock market data in Japan, in contrast to the results of Chen, Roll, and Ross [17], Ng [18], Gonzáles-Rivera [19], or Hall, Miles, and Taylor [20], where the traditional CAPM was not supported.

\section{INTERPRETATION}

This section supplies interpretation for the prices of risk presented in Table 3. We here explicitly discuss the pronounced fall of the risk prices after 1986 and their subsequent sharp rise after 1997. Below, we interpret the results by relating these movements of risk prices to, first, the heyday of the, so called, 'bubble economy' in the late 1980s in

tember of year $t+1$, after rebalancing portfolios in every September of year $t$, to be sure that the book equity for the most recent fiscal year is known in the Japanese market.

5 The BE/ME-ranked portfolios were formed according to the manner of Fama and French [7] as the size-ranked portfolios. 
Table 1. Monthly Time-Varying Price of Risk on 25 Portfolios Formed on the Basis of Size: The Case of the Conditional CAPM in Japan from January 1982 to December 2003

\begin{tabular}{|c|c|c|c|c|c|c|c|c|c|c|c|c|c|}
\hline & & Jan. & Feb. & Mar. & Apr. & May & Jun. & Jul. & Aug. & Sep. & Oct. & Nov. & Dec. \\
\hline \multirow[t]{2}{*}{1982} & & & & & & & & & & & & & \\
\hline & $p$-value & 0.0 & & & & & & & & 0.001 & & & 0.003 \\
\hline \multirow[t]{2}{*}{1983} & Risk price & $0.138 * *$ & $0.089^{* *}$ & $0.285^{* *}$ & $0.236^{* *}$ & $0.168^{* *}$ & $0.102 *$ & $0.304^{* *}$ & $0.162^{* *}$ & 0.023 & $0.064 *$ & $0.093^{* *}$ & $0.321 * *$ \\
\hline & $p$-value & 0.002 & 0.004 & 0.000 & 0.000 & 0.000 & 0.014 & 0.000 & 0.000 & 0.381 & 0.047 & 0.000 & 0.000 \\
\hline \multirow[t]{2}{*}{1984} & Risk price & $0.279 * *$ & 0.052 & $0.247^{* *}$ & -0.008 & $-0.274 * *$ & $0.123^{* *}$ & -0.008 & $0.219^{*}$ & 0.019 & $0.219^{* *}$ & $0.146^{* *}$ & 0.009 \\
\hline & $p$-value & 0.000 & 0.127 & 0.000 & 0.765 & 0.000 & 0.000 & 0.856 & 0.037 & 0.489 & 0.0 & 0.000 & 0.677 \\
\hline \multirow[t]{2}{*}{1985} & Risk price & $0.179 * *$ & $0.135^{*}$ & $0.081 * *$ & 0.013 & $0.214 * *$ & $0.149 * *$ & -0.001 & $0.256^{* *}$ & $0.182 * *$ & $0.117^{* *}$ & $0.139 * *$ & $0.101 * *$ \\
\hline & $p$-value & 0.000 & 0.022 & 0.000 & 0.567 & 0.000 & 0.000 & 0.980 & 0.000 & 0.000 & 0.001 & 0.001 & 0.000 \\
\hline \multirow[t]{2}{*}{1986} & Risk price & $0.169 * *$ & $0.405 * *$ & 0.371 & 0.087 & $0.153^{* *}$ & $0.333^{* *}$ & 0.009 & 0.058 & $-0.229 * *$ & -0.026 & $0.401^{* *}$ & -0 . \\
\hline & $p$-value & 0.000 & 0.000 & 0.000 & 0.055 & 0.001 & 0.000 & 0.789 & 0.358 & 0.008 & 0.122 & 0.0 & 0.025 \\
\hline \multirow[t]{2}{*}{1987} & Risk price & $0.144 * *$ & $0.135^{* *}$ & $0.069^{* *}$ & $0.136^{* *}$ & $0.611^{* *}$ & 0.14 & $0.297^{* *}$ & 0.31 & $0.086^{* *}$ & -0.2 & -0.0 & \\
\hline & $p$-value & 0.000 & 0.000 & 0.006 & 0.000 & 0.000 & 0.0 & 0.006 & 0.00 & 0.000 & 0.0 & 0.0 & 0.168 \\
\hline \multirow[t]{2}{*}{1988} & Risk price & 0.452 & $0.194 * *$ & 0.076 & 0.24 & $0.142^{* *}$ & $0.114 * *$ & $-0.122 * *$ & $-0.084 * *$ & & $-0.063^{* *}$ & & $0.062 * *$ \\
\hline & $p$-value & 0.00 & 0.000 & 0.00 & 0.000 & 0.000 & 0.0 & 0.002 & 0.005 & 0.257 & 0.005 & 0.0 & 0.002 \\
\hline \multirow[t]{2}{*}{1989} & Risk price & 0.425 & -0.032 & 0.16 & 0.21 & 0.17 & -0.0 & 0.27 & 0.10 & 0.35 & 0.0 & 0.20 & $0.178^{* *}$ \\
\hline & $p$-value & 0.00 & 0.090 & 0.00 & 0.000 & 0.0 & & & & 0.000 & 0.483 & & 0.000 \\
\hline \multirow[t]{2}{*}{1990} & Risk price & -0.028 & -0.12 & $-0.4 c$ & -0.0 & 0.40 & & 0.018 & -0.5 & -0.3 & 0.2 & -0.1 & 0.003 \\
\hline & $p$-value & 0.50 & 0.00 & 0.0 & 0.0 & 0.0 & & & & 0.000 & & 0.0 & 0.612 \\
\hline \multirow[t]{2}{*}{1991} & Risk price & -0.07 & 0.32 & 0.03 & 0.004 & -0.001 & -0.1 & -0. & -0.2 & 0.18 & & -0.2 & \\
\hline & $p$-value & 0.00 & 0.00 & 0.00 & & 0.7 & & & & 0.0 & & 0.0 & 0.068 \\
\hline \multirow[t]{2}{*}{1992} & Risk price & -0.08 & $-0.041^{* *}$ & -0.24 & $-0.179 * *$ & $0.187^{* *}$ & -0.2 & -0.1 & 0.2 & -0.06 & -0.0 & 0.0 & 0.005 \\
\hline & $p$-va & 0.000 & 0.000 & 0.000 & 0.000 & 0.000 & 0.0 & 0.0 & 0.000 & 0.000 & 0.0 & 0.0 & 0.738 \\
\hline \multirow[t]{2}{*}{1993} & Risk price & $-0.053 * *$ & 0.002 & $0.507 * *$ & $0.349 * *$ & $0.158 * *$ & $-0.131 * *$ & $0.068 * *$ & $0.050^{* *}$ & $-0.075 * *$ & -0.16 & -0.5 & $0.101 * *$ \\
\hline & $p$-value & 0.000 & 0.834 & 0.000 & 0.000 & 0.000 & 0.000 & 0.000 & 0.000 & 0.000 & 0.0 & 0.0 & 0.0 \\
\hline \multirow[t]{2}{*}{1994} & Risk price & 0.330 & 0.02 & 0.014 & $0.080 * *$ & 0.10 & 0.08 & -0.05 & -0.0 & -0.18 & 0.0 & -0.2 & 0.10 \\
\hline & $p$-val & 0.000 & 0.00 & 0.296 & 0.000 & 0.000 & 0.0 & 0.0 & 0.0 & & & & 0.000 \\
\hline \multirow[t]{2}{*}{1995} & Risk price & -0.14 & -0.31 & -0.11 & 0.015 & -0.30 & -0.12 & 0.40 & 0.28 & & 0.0 & 0.19 & $0.261 * *$ \\
\hline & $p$-va & 0.000 & 0.000 & 0.000 & 0.052 & 0.000 & 0.000 & 0.000 & 0.000 & 0.221 & 0.6 & 0.0 & 0.000 \\
\hline \multirow[t]{2}{*}{1996} & Risk p & $0.194 * *$ & -0.10 & 0.192 & $0.299^{* *}$ & $-0.025^{*}$ & $0.044^{* *}$ & -0.3 & -0.04 & $0.152 * *$ & $-0.156^{* *}$ & $-0.061 * *$ & $-0.329 * *$ \\
\hline & $p$-valı & 0.000 & 0.000 & 0.000 & 0.000 & 0.045 & 0.006 & 0.000 & 0.004 & 0.000 & 0.000 & 0.001 & 0.000 \\
\hline \multirow[t]{2}{*}{1997} & Risk price & $-0.128 * *$ & 0.006 & $-0.120 * *$ & $0.113^{* *}$ & $0.293^{* *}$ & $0.074 * *$ & $-0.151^{* *}$ & $-0.350 * *$ & $-0.302 * *$ & $0.085^{*}$ & $-0.341^{* *}$ & $-0.388^{* *}$ \\
\hline & $p$-value & 0.000 & 0.636 & 0.000 & 0.000 & 0.000 & 0.000 & 0.001 & 0.000 & 0.000 & 0.014 & 0.000 & 0.000 \\
\hline \multirow[t]{2}{*}{1998} & Risk price & $0.641^{* *}$ & $0.128 * *$ & $-0.051^{* *}$ & $-0.109^{* *}$ & $0.039^{* *}$ & & 0.115 & $-0.381 * *$ & $-0.148 * *$ & $-0.026^{*}$ & & $-0.143^{* *}$ \\
\hline & $p$-value & 0.000 & 0.00 & 0.000 & 0.000 & 0.001 & 0.001 & 0.000 & 0.000 & 0.000 & 0.025 & 0.000 & 0.000 \\
\hline \multirow[t]{2}{*}{1999} & Risk price & $0.086^{* *}$ & $0.035^{*}$ & & $0.248^{* *}$ & -0.014 & & $0.071 * *$ & -0.009 & 0.014 & $-0.074 * *$ & -0.074 & $-0.152^{*}$ \\
\hline & $p$-value & 0.000 & 0.017 & 0.000 & 0.000 & 0.602 & 0.000 & 0.000 & 0.485 & 0.502 & 0.000 & 0.140 & 0.014 \\
\hline \multirow[t]{2}{*}{2000} & Risk price & $0.263^{* *}$ & 0.033 & $0.258^{* *}$ & $-0.114 * *$ & $0.200^{* *}$ & $0.713^{* *}$ & $-0.213 * *$ & $0.153^{* *}$ & $-0.066^{* *}$ & $-0.273 * *$ & $0.107^{* *}$ & $-0.141^{* *}$ \\
\hline & $p$-value & 0.000 & 0.356 & 0.000 & 0.009 & 0.000 & 0.000 & 0.001 & 0.000 & 0.000 & 0.000 & 0.000 & 0.000 \\
\hline \multirow[t]{2}{*}{2001} & Risk price & $0.065^{* *}$ & $0.104 * *$ & $0.316^{* *}$ & $0.414 * *$ & $-0.078 * *$ & $0.144 * *$ & $-0.251 * *$ & -0.048 & $-0.241 * *$ & $0.199 * *$ & $-0.086^{* *}$ & $-0.153^{* *}$ \\
\hline & $p$-value & & & & & & 0.000 & & 0.080 & 0.000 & 0.000 & 0.000 & 0.000 \\
\hline 2002 & Risk price & $-0.064 *$ & $0.288 * *$ & $0.153 * *$ & $0.136^{* *}$ & $0.279^{* *}$ & $-0.290 * *$ & $-0.055^{* *}$ & $-0.063 * *$ & -0.023 & $-0.270 * *$ & 0.022 & $-0.127 * *$ \\
\hline & $p$-value & 0.028 & 0.000 & 0.000 & & & & & 0.000 & 0.058 & 0.000 & 0.328 & 0.000 \\
\hline 2003 & Risk price & $0.072 *$ & $0.262^{* *}$ & $0.059^{*}$ & $0.295^{* *}$ & $0.431^{* *}$ & $0.528^{* *}$ & 0.049 & $0.284 * *$ & $0.136^{* *}$ & $0.144^{* *}$ & $-0.220 * *$ & $0.158 * *$ \\
\hline & & 0.018 & 0.000 & 0.020 & 0.000 & 0.000 & 0.000 & 0.093 & 0.000 & 0.000 & 0.000 & 0.000 & 0.000 \\
\hline
\end{tabular}

Notes: Monthly time-varying price of risk on 25 size-ranked portfolios are displayed for the sample period from January 1982 to December 2003 . The risk prices of the conditiona CAPM are calculated using conditional time-varying covariances from a multivariate GARCH model. The portfolios are formed according to the procedures in Fama and French [7]; that is, at the end of September of each year $t$ (1981-2003), TSE First Section stocks are allocated to one of 25 groups based on their September market equity (ME, stock price $\times$ shares outstanding). Value-weighted monthly returns on the portfolios are then calculated from October to the following September. Only firms with ordinary common equity are included. REITs (real estate investment trusts) and units of beneficial interest are excluded. The $p$-values are calculated using the heteroskedasticity consistent covariance matrix of White [16]. The symbols, ${ }^{* *}$ and ${ }^{*}$, denote statistical significance at the $1 \%$ and $5 \%$ levels, respectively.

Japan and, second, the onset of the Asian financial crisis in 1997.

In our conditional version of the CAPM (4), as Cochrane [21, p. 167] suggested, the time-varying price of risk, $\delta_{t}$ can be interpreted as the time-varying risk aversion of the market participants. From this economic viewpoint, in the Japanese 'bubble economy' in the late 1980s, the decrease of the risk price $\delta_{t}$ in our sub-period from January 1987 to December 1992 in Table 3 can be interpreted as showing that the degree of risk aversion of investors was low in that period because of the relatively good market condition in the period in Japan. 
Table 2. Monthly Time-Varying Price of Risk For Twenty-Five Portfolios Formed on the Basis of BE/ME: The Case of the Conditional CAPM in Japan from January 1982 to December 2003

\begin{tabular}{|c|c|c|c|c|c|c|c|c|c|c|c|c|c|}
\hline & & an. & Feb. & Mar. & Apr. & May & Jun. & Jul. & Aug. & Sep. & Oct. & Nov. & Dec. \\
\hline \multirow[t]{2}{*}{1982} & & & & & & & & & & $5 * *$ & & $7 * *$ & $5^{* *}$ \\
\hline & & & & & & & & 0.001 & 0.119 & 0.001 & 0.000 & 0.000 & 0.000 \\
\hline \multirow[t]{2}{*}{1983} & Risk price & -0.053 & 0.034 & $0.277 * *$ & $0.131 * *$ & $0.070^{*}$ & $0.138^{* *}$ & $0.130^{* *}$ & $0.111^{* *}$ & $0.091 * *$ & -0.003 & 0.031 & $0.379^{* *}$ \\
\hline & $p$-value & 0.071 & 0.159 & 0.000 & 0.000 & 0.020 & 0.000 & 0.000 & 0.000 & 0.001 & 0.889 & 0.140 & 0.000 \\
\hline \multirow[t]{2}{*}{1984} & Risk price & $0.150 * *$ & $-0.073^{* *}$ & $0.317^{* *}$ & -0.030 & $-0.305 * *$ & $0.087^{* *}$ & $-0.094 * *$ & $0.279 * *$ & 0.030 & $0.128 * *$ & 0.005 & $0.125^{* *}$ \\
\hline & $p$-value & 0.000 & 0.005 & 0.000 & 0.172 & 0.000 & 0.000 & 0.000 & 0.000 & 0.113 & 0.000 & 0.856 & 0.009 \\
\hline \multirow[t]{2}{*}{1985} & Risk price & 0.064 & 0.033 & 0.073 & -0.022 & $0.202^{* *}$ & $0.091 * *$ & -0.119 & $0.193 * *$ & $0.226^{* *}$ & 0.017 & -0.026 & $0.144^{* *}$ \\
\hline & $p$-val & 0.1 & 0.108 & 0.06 & 0.447 & 0.0 & 0.004 & 0.077 & 0.000 & 0.0 & 0.789 & 0.360 & 0.000 \\
\hline \multirow[t]{2}{*}{1986} & Risk price & 0.028 & $0.288^{* *}$ & $0.653 *$ & 0.042 & $0.110^{* *}$ & $0.184 * *$ & $0.236^{* *}$ & $0.209 * *$ & -0.019 & $-0.121 * *$ & $0.278^{* *}$ & $0.067^{* *}$ \\
\hline & $p$-va & 0.178 & 0.000 & 0.0 & 0.114 & 0.0 & 0.0 & 0.004 & 0.003 & 0.6 & 0.000 & 0.000 & 0.000 \\
\hline \multirow[t]{2}{*}{1987} & Risk price & $0.114 * *$ & $0.107 * *$ & $0.092 *$ & $0.191^{* *}$ & $0.317^{* *}$ & 0.040 & $0.052 *$ & $0.240 * *$ & $0.121^{*}$ & $-0.413 * *$ & $-0.060 * *$ & $-0.086^{* *}$ \\
\hline & $p$-va & 0.007 & 0.008 & 0.031 & 0.001 & & 0.2 & 0.017 & 0.000 & 0.011 & 0.0 & 0.000 & 0.009 \\
\hline \multirow[t]{2}{*}{1988} & Risk price & $0.323 * *$ & $0.202 * *$ & $0.107 * *$ & $0.159 * *$ & -0.02 & $0.16^{\circ}$ & 0.14 & $-0.200 * *$ & 0.0 & -0.007 & $0.251^{* *}$ & $0.128 *$ \\
\hline & $p$-value & 0.000 & & & & & & & & & & & 19 \\
\hline \multirow[t]{2}{*}{1989} & Risk price & 0.261 & 0.013 & 0.11 & 0.12 & 0.12 & $-0.1^{\prime}$ & 0.310 & -0.046 & 0.20 & -0. & $0.170 * *$ & $0.084 * *$ \\
\hline & & 0.0 & & & & & & & & & & & \\
\hline \multirow[t]{2}{*}{1990} & Risk price & -0.15 & $-0.208^{* *}$ & -0.43 & 0.016 & $0.30^{\top}$ & -0.0 & $-0.0^{7}$ & $-0.427 * *$ & -0.4 & 0.25 & -0.1 & 0.03 \\
\hline & $p$-value & 0.0 & & & 0.2 & & & & 0.0 & & 0.0 & 0.0 & 0.0 \\
\hline \multirow[t]{2}{*}{1991} & Risk price & $-0.044 * *$ & $0.356^{* *}$ & 0.002 & $-0.022 * *$ & $-0.023 *$ & -0.2 & $0.030 * *$ & $-0.261 * *$ & $0.227 * *$ & $0.054^{* *}$ & -0.319 & -0.007 \\
\hline & & 0.000 & 0.00 & 0.6 & & & & & & & 0.0 & & 0.2 \\
\hline \multirow[t]{2}{*}{1992} & Risk $\mathrm{p}$ & $-0.094 * *$ & $-0.097 * *$ & $-0.273 * *$ & -0.12 & $0.142 * *$ & -0.3 & -0.0 & $0.330^{* *}$ & -0.1 & -0.06 & $0.093 * *$ & -0.0 \\
\hline & & 0.000 & & & & & & & & & & & 0.0 \\
\hline \multirow[t]{2}{*}{1993} & Risk price & -0.018 & $-0.034^{*}$ & $0.563^{* *}$ & $0.331 * *$ & 0.010 & -0.13 & $0.117^{* *}$ & $0.066 * *$ & $-0.0^{\top}$ & $-0.044 * *$ & -0.56 & $0.107^{* *}$ \\
\hline & & 0.0 & 0.0 & & & & & & & & & & \\
\hline \multirow[t]{2}{*}{1994} & Risk & $0.355^{* *}$ & $0.024 *$ & $-0.071 * *$ & $0.058 * *$ & $0.133^{* *}$ & 0.023 & -0.07 & $0.034^{*}$ & -0.14 & $0.025 * *$ & $-0.171 * *$ & $0.082^{* *}$ \\
\hline & & & & & & & & & 0.013 & & & & 0.0 \\
\hline \multirow[t]{2}{*}{1995} & Risk price & $-0.273 * *$ & $-0.266^{* *}$ & $-0.047 * *$ & 0.016 & $-0.255^{* *}$ & $-0.096 * *$ & $0.411 * *$ & $0.268 * *$ & $0.027 *$ & -0.015 & $0.148 * *$ & $0.244 * *$ \\
\hline & & & & & & & & & & & 0.1 & 0.0 & 0.0 \\
\hline \multirow[t]{2}{*}{1996} & Risk price & $0.140 * *$ & $-0.092 * *$ & $0.182 * *$ & $0.229 * *$ & $-0.054 * *$ & $0.104 * *$ & $-0.301 * *$ & $-0.085^{* *}$ & $0.213^{* *}$ & $-0.168 * *$ & 0.035 & $-0.176^{* *}$ \\
\hline & $p$-va & & & & & & & & & & & 0.1 & \\
\hline \multirow[t]{2}{*}{1997} & Risk price & $-0.118^{* *}$ & $0.030^{*}$ & -0.022 & $0.254^{* *}$ & $0.172 * *$ & $0.108^{* *}$ & 0.045 & $-0.341^{* *}$ & $-0.094 *$ & -0.049 & $-0.166^{* *}$ & $-0.268 * *$ \\
\hline & $p$-value & 0.000 & 0.043 & & & & & 0.192 & 0.000 & 0.016 & 0.223 & 0.001 & 0.000 \\
\hline \multirow[t]{2}{*}{1998} & Risk price & $0.442 * *$ & $0.088^{* *}$ & -0.015 & $-0.107 * *$ & $0.068^{* *}$ & $0.076^{* *}$ & $0.179 * *$ & $-0.471 * *$ & $-0.109 * *$ & $-0.037 *$ & $0.405^{* *}$ & $-0.108 * *$ \\
\hline & $p$-val & 0.000 & & & & & & & & 0.000 & 0.029 & 0.0 & 0.000 \\
\hline \multirow[t]{2}{*}{1999} & Risk price & $0.110^{* *}$ & 0.009 & $0.524 * *$ & $0.211^{* *}$ & $-0.032 *$ & $0.368^{* *}$ & $0.107 * *$ & $-0.049 *$ & 0.050 & -0.062 & -0.007 & 0.087 \\
\hline & $p$-va & 0.000 & 0.546 & & & 0.020 & 0.000 & 0.000 & 0.031 & 0.105 & 0.166 & 0.936 & 0.462 \\
\hline \multirow[t]{2}{*}{2000} & Risk price & 0.070 & 0.030 & $0.222^{* *}$ & -0.069 & 0.125 & 0.460 ** & $-0.211 * *$ & $0.134 * *$ & $-0.063 *$ & $-0.182 * *$ & $0.126^{* *}$ & $-0.096^{*}$ \\
\hline & $p$-value & 0.227 & 0.549 & 0.000 & 0.067 & 0.055 & 0.000 & 0.000 & 0.000 & 0.023 & 0.000 & 0.000 & 0.011 \\
\hline \multirow[t]{2}{*}{2001} & Risk price & 0.050 & 0.039 & $0.264^{* *}$ & $0.473^{* *}$ & $-0.068 * *$ & $0.123 * *$ & $-0.243^{* *}$ & $-0.123^{* *}$ & $-0.214^{* *}$ & $0.137^{* *}$ & $-0.066^{*}$ & $-0.074 * *$ \\
\hline & $p$-value & 0.076 & 0.399 & 0.000 & 0.000 & 0.000 & 0.001 & 0.000 & 0.004 & 0.000 & 0.000 & 0.049 & 0.001 \\
\hline 2002 & Risk price & $-0.138 * *$ & 0.252 & $0.164 * *$ & $0.115^{* *}$ & $0.260^{* *}$ & $-0.284 * *$ & $-0.108^{* *}$ & $-0.060 * *$ & -0.015 & $-0.201 * *$ & $0.086^{* *}$ & $-0.125^{* *}$ \\
\hline & $p$-value & 0.000 & 0.000 & 0.000 & 0.000 & 0.000 & 0.000 & 0.000 & 0.000 & 0.533 & 0.000 & 0.003 & 0.000 \\
\hline 2003 & Risk price & -0.010 & $0.153^{* *}$ & -0.025 & $0.176^{* *}$ & $0.307^{* *}$ & $0.438^{* *}$ & $0.087^{* *}$ & $0.274 * *$ & $0.108^{* *}$ & $0.161^{* *}$ & $-0.189 * *$ & $0.210^{* *}$ \\
\hline & $p$-value & 0.709 & 0.000 & 0.244 & 0.000 & 0.000 & 0.000 & 0.006 & 0.000 & 0.001 & 0.000 & 0.000 & 0.000 \\
\hline
\end{tabular}

Notes: Monthly time-varying price of risk on 25 BE/ME-ranked portfolios are displayed for the period from January 1982 to December 2003 . The risk prices of the conditional CAPM are calculated using the conditional time-varying covariances derived from the multivariate GARCH model. The portfolios are formed according to the procedures in Fama and French [7] by using the TSE First Section stocks. That is, the BE/ME ratios used to form portfolios in September of year $t$ is the book common equity for the fiscal year $t$-1, divided by the market equity at the end of March in calendar year $t$. We do not use negative BE firms when forming the BE/ME portfolios. Value-weighted monthly returns on the portfolios are then calculated from October to the following September. Only firms with ordinary common equity are included. REITs (real estate investment trusts) and units of beneficial interest are excluded. The $p$-values are calculated by using the heteroskedasticity consistent covariance matrix of White [16]. The symbols, $* *$ and $*$, denote statistical significance at the $1 \%$ and $5 \%$ levels, respectively.

On the other hand, since the Asian financial crisis in 1997, it has been very natural to conclude that the degree of risk aversion of investors increased due to their negative sentiments and the condition of the Japanese financial markets. As a result, we consider that, due to the above macroeconomic context of the financial crisis, from the sub-period of January 1998 to July 2004 in Table 3, values of the parameter $\delta_{t}$ again increased in Japan.

As above, changes of the risk prices in Table $\mathbf{3}$ can be interpreted by using the economic notion of time-varying risk aversion, as Cochrane [21] suggested, and which follows 
Table 3. Panel Data Analysis of the Time-Varying Prices of Risk on 25 Portfolios Formed on the Basis of Size and BE/ME: The Case of the Conditional CAPM in Japan from October 1981 to July 2004

\begin{tabular}{|c|c|c|c|}
\hline \multicolumn{2}{|c|}{$\begin{array}{c}\text { Panel A } \\
\text { Results of } 25 \text { portfolios formed on size }\end{array}$} & \multicolumn{2}{|c|}{$\begin{array}{c}\text { Panel B } \\
\text { Results of } 25 \text { portfolios formed on BE/ME }\end{array}$} \\
\hline Risk Price & $p$-Value & Risk Price & $p$-Value \\
\hline \multicolumn{2}{|c|}{ From October 1981 to July 2004} & \multicolumn{2}{|c|}{ From October 1981 to July 2004} \\
\hline $0.0382 * *$ & 0.0000 & $0.0351 * *$ & 0.0000 \\
\hline \multicolumn{2}{|c|}{ From October 1981 to December 1986} & \multicolumn{2}{|c|}{ From October 1981 to December 1986} \\
\hline $0.0952 * *$ & 0.0000 & $0.0756^{* *}$ & 0.0000 \\
\hline \multicolumn{2}{|c|}{ From January 1987 to December 1992} & \multicolumn{2}{|c|}{ From January 1987 to December 1992} \\
\hline $0.0146^{* *}$ & 0.0015 & 0.0074 & 0.1278 \\
\hline \multicolumn{2}{|c|}{ From January 1993 to December 1997} & \multicolumn{2}{|c|}{ From January 1993 to December 1997} \\
\hline $0.0205^{* *}$ & 0.0002 & $0.0222 * *$ & 0.0000 \\
\hline \multicolumn{2}{|c|}{ From January 1998 to July 2004} & \multicolumn{2}{|c|}{ From January 1998 to July 2004} \\
\hline $0.0687 * *$ & 0.0000 & $0.0619^{* *}$ & 0.0000 \\
\hline
\end{tabular}

Notes: Monthly time-varying prices of risk on 25 portfolios formed on the basis of size and BE/ME ratios are evaluated, for the period from October 1981 to July 2004 , using pane data. The evaluation is performed for the whole sample period and for four sub-sample periods. The risk prices of the conditional CAPM are calculated using the conditional timevarying covariances derived from the multivariate GARCH model. The size and BE/ME ratio portfolios are formed according to Fama and French [7] by using the TSE First Section stocks. That is, in constructing the size portfolios, at the end of September of each year $t$ (1981-2003), TSE First Section stocks are allocated to one of 25 groups based on their September market equity. Value-weighted monthly returns on the size portfolios are then calculated from October to the following September. When constructing the BE/ME portfolios, the BE/ME ratio used to form portfolios in September of year $t$ is the book common equity for the fiscal year $t-1$, divided by market equity at the end of March in calendar year $t$. We do not use negative BE firms when forming the BE/ME portfolios. The value-weighted monthly returns on the BE/ME portfolios are then calculated from October to the following September. Only firms with ordinary common equity are included. This means that REITs (real estate investment trusts) and units of beneficial interest are excluded. The symbols ** attached to the coefficients denotes the statistical significance at the $1 \%$ level.

the framework of the intertemporal CAPM, suggested by Merton [22].

\section{CONCLUSIONS}

This paper has originally and minutely investigated the degree of pricing of the month-by-month time-varying risks on the Japanese stock market using a multivariate GARCH model. We demonstrated that conditional covariance risks in the CAPM, derived by a multivariate GARCH model, are generally positively priced in Japan. Rather than the timevarying covariance risks analyzed in many other studies, the clarification of the situation in regard to the time-varying risk prices was our focus and primary contribution in this paper. In many studies in the preceding literature, the degree of the pricing of covariance risks on a monthly basis is not clear. In addition, using our method to derive the time series of risk prices is expected to clarify the unrevealed economic characteristics of these time series. This is one of our important future tasks.

Furthermore, as pointed out earlier, studies using multivariate GARCH models in the field of asset pricing are limited. Hence, international research using this model in the field of asset pricing like ours would be valuable to the financial economics literature.

\section{ACKNOWLEDGMENTS}

I acknowledge the generous financial assistance of the Japan Society for the Promotion of Science. I would also like to thank Jason McQueen, Nick Wade, Takao Kobayashi, Geert Bekaert, Giorgio Szego, and Ike Mathur for the helpful information related to this paper. Furthermore, I particularly appreciate the very supportive and constructive comments from two anonymous referees of this journal. Finally, I greatly appreciate the kind invitation of Mehwish Akhter and Humaira Bilal to write for this new journal.

\section{REFERENCES}

[1] Harvey CR. Time-varying conditional covariances in tests of asset pricing models. J Finance Econ 1989; 24: 289-317.

[2] Campbell J. Understanding risk and return. J Polit Econ 1996; 104: 298-345.

[3] Hansson B, Hördahl P. Testing the conditional CAPM using multivariate GARCH-M. Appl Finan Econ 1998; 8: 377-88.

[4] Guo H. Time-varying risk premia and the cross section of stock returns. J Bank Finance 2006; 30: 2087-107.

[5] Sharpe W. Capital asset prices: A theory of market equilibrium under conditions of risk. J Finance 1964; 19: 425-42.

[6] Lintner J. The valuation of risky assets and the selection of risky investments in stock portfolios and capital budgets. Rev Econ Stat 1965; 47: 13-37.

[7] Fama E, French K. Common risk factors in the returns on stocks and bonds. J Finance Econ 1993; 33: 3-56.

[8] Bollerslev T., Engle RF, Wooldridge JM. A capital asset pricing model with time-varying covariances. J Polit Econ 1988; 96: 11631.

[9] Engle RF, Kroner KF. Multivariate simultaneous generalized ARCH. Economet Theor 1995; 11: 122-50.

[10] Koutmos G, Booth GG. Asymmetric volatility transmissions in international stock markets. J Int Money Finance 1995; 14: 747-62.

[11] Braun PA, Nelson DB, Sunier AM. Good news, bad news, volatility, and betas. J Finance 1995; 50, 1575-603.

[12] Kroner KF, Ng VK. Modelling asymmetric comovement of assets returns. Rev Finance Stud 1998; 11: 817-44.

[13] Leon A, Nave JM, Rubio G. The relationship between risk and expected return in Europe. J Bank Financ 2007; 31: 495-512.

[14] Bauens L, Laurent S, Rombouts JVK. Multivariate GARCH models: A survey. J Appl Econom 2006; 21: 79-110.

[15] Hamao Y. An empirical examination of the arbitrage pricing theory. Jpn World Econ 1988; 1: 45-61. 
[16] White H. A Heteroskedasticity-Consistent Covariance Matrix Estimator and Direct Test for Heteroskedasticity. Econometrica 1980; 48: 817-38.

[17] Chen N, Roll R, Ross S. Economic forces and the stock market. J Bus 1986; 59: 383-403.

[18] Ng L. Tests of the CAPM with time-varying covariances: A multivariate GARCH approach. J Finance 1991; 46: 1507-21.
[19] Gonzáles-Rivera G. Time-varying risk: The case of the American computer industry. J Empir Finance 1996; 2: 333-42.

[20] Hall SG, Miles DK, Taylor MP. Modelling asset prices with timevarying betas. Manchester School 1989; 57: 340-56.

[21] Cochrane JH. Asset Pricing; Princeton University Press: New Jersey 2005.

[22] Merton RC. An intertemporal capital asset pricing model. Econometrica 1973; 41: 867-87.

(C) Chikashi Tsuji; Licensee Bentham Open

This is an open access article licensed under the terms of the Creative Commons Attribution Non-Commercial License (http://creativecommons.org/licenses/by$\mathrm{nc} / 3.0 /$ ) which permits unrestricted, non-commercial use, distribution and reproduction in any medium, provided the work is properly cited. 